\title{
Evaluating soil quality at a landfill: a study case from morocco (tangier)
}

\author{
Ikram Chaer ${ }^{1,2}$, Asmae El Cadi ${ }^{1}$, Jamal Brigui ${ }^{2}$, Khadija Ziat ${ }^{1}$ and Mohamed Khaddor ${ }^{1, *}$ \\ ${ }^{1}$ Laboratory of physicochemical materials, natural substances and environment, Departement of Chemistry, \\ Faculty of Sciences and Technology, Abdelmale Essaâdi University, Tangier, Morocco \\ ${ }^{2}$ Laboratory of Materials and Valorization of Resources, Departement of Chemistry, Faculty of Sciences and \\ Technology, Abdelmale Essaâdi University, Tangier, Morocco
}

\begin{abstract}
In recent decades, landfill sites have been a potential source of contamination, which can hurt the environment due to the accumulation of heavy metals and processed organic products. In the Tangier landfill, the different types of wastes are missing any prior treatment or any soil of protection. This behavior constitutes a risk factor of contamination for the soil and groundwater. Between the waste and soil, many physicochemical and biological reactions occur. The objective of this work effort is to derive a global and in-depth characterization of the organic and mineral matter of the soil samples from the Tangier landfill. The study of organic matter (OM) in soils help to understand the evolution of soil contamination. Eight samples of soil have been studied using a range of chemical and physical analytical methods. FT-IR spectroscopy and X-ray diffraction analyses have used to investigate the nature of organic matter. The analysis of heavy metals in the soil showed that there is a significant presence of $\mathrm{Pb}, \mathrm{Cd}, \mathrm{As}, \mathrm{Cr}$ and $\mathrm{Zn}$ quantities which are mainly due to industrial waste.
\end{abstract}

Keywords: Wastes; Landfill; Organic matter; FT-IR spectroscopy; X-ray diffraction; Heavy metals.

\section{Introduction}

The increase of industries and the population growth in the world has led to considerable growth of contaminating waste, which must be well managed to avoid the transfer of environmental pollution ${ }^{1,2}$. Implementing solid landfill waste without any prior treatment or any protection of the soil in the landfill sites constitutes a risk factor of contamination for soil surface and groundwater. The landfill is the most common way of storing waste around the world. This practice leads to gaseous emissions and liquid leachates that are produced after waste decomposition 3 and rainwater percolation ${ }^{1,4,5}$. Their composition varies considerably, depending on the origin and nature of the disposed waste, the landfill geographic location and the climate conditions ${ }^{4,6}$. There are different types of pollution, mainly chemical, physical, radioactive and biological pollution. This study aims to provide baseline data on the chemical and metal pollution contained in the soil in northern Moroccan city (Tangier). Large quantities of heavy metals (in solid forms) have buried during the storage of municipal or industrial waste. The purpose of this study is to investigate mainly the organic parameters and the total concentrations $(\mathrm{mg} / \mathrm{kg}$ dry matter) of metals $\mathrm{Zn}, \mathrm{Cr}, \mathrm{Pb}, \mathrm{Cd}$, and As to assess and quantify the organic and metallic pollution, and learn about

*Corresponding author: Mohamed Khaddor

Email address: mohamedkhaddor@yahoo.fr

DOI: http://dx.doi.org/10.13171/mjc94191119973mk how urban and industrial activities may generate this pollution. Moreover, MEB, X-ray diffraction and spectroscopic analyses (FT-IR, UV-visible) have been used to investigate the organic and the inorganic matter nature of the soils. For FT-IR analysis, we focused on the absorption bands in the region of $400-1000 \mathrm{~cm}-1$ to obtain detailed information about organic matter nature of soils.

\section{Materials and methods}

\subsection{Sites}

The landfill of Tangier city is uncontrolled and open, is located southeast of the town $5 \mathrm{~km}$ from the city center on the road (RN2) to Tetouan, and it extends on a flat of 20 ha. It has been put into operation since early 1970 on a land belonging to the private domain of the State. The landfill is located on hills surrounded by the valleys of the bottom Moghogha and Ghir Boudra south and those bottoms Mlaleh Khandak and Bou Hajjar of east. The quantity of waste has closely linked to population ratio and the production of waste.

\subsection{Soil samples}

Eight samples have been collected from the surface layer of soil $(0-20 \mathrm{~cm})$ of the uncontrolled landfill of tangier Figure1. These obtained samples from the landfill have been manually sorted to remove metal,

Received June 9, 2019

Accepted September 12, 2019

Published November 19, 2019 
plastic, glass, and stone. Residual samples were ground, and sieved particles smaller than $2 \mathrm{~mm}$ in diameter have been used for analyses.

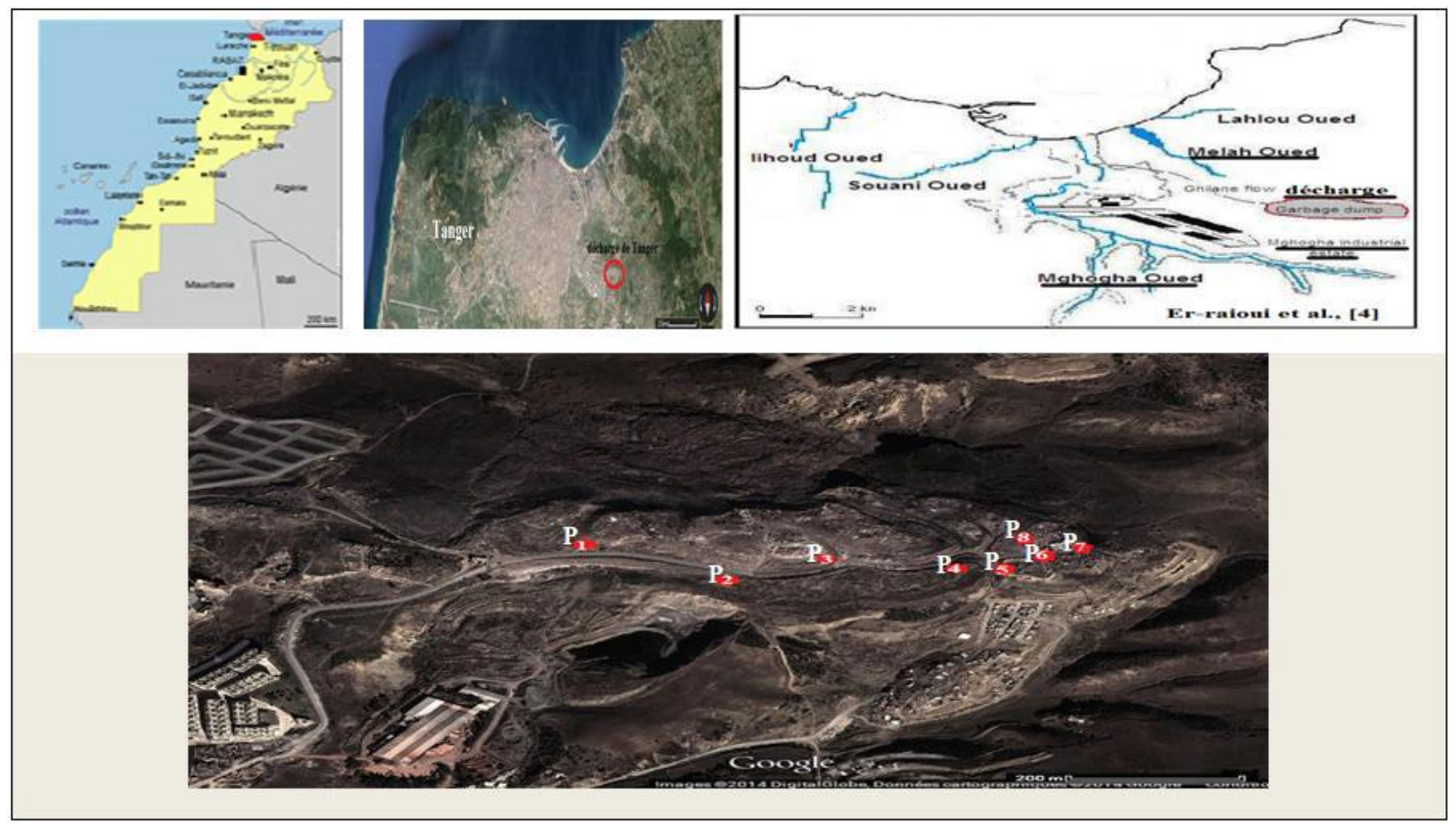

Figure 1. Location of the study area

The soil giving rise to the landfill is a forest floor (Charf al Aakab) of the Vertisol type (is a soil in which there is a high content of expansive clay minerals), characterized by a vegetation of Eucalyptus and by a water table flush with physicochemical growths following Table 1:

Table 1. Some Physico-chemical parameters of Charf al Aakab.

\begin{tabular}{|c|c|c|c|c|c|c|c|c|c|c|c|c|}
\hline $\mathrm{pH}$ & $\mathrm{OM} \%$ & $\begin{array}{c}\mathrm{EC} \\
\mathrm{ms} / \mathrm{cm}\end{array}$ & $\mathrm{CaCO}_{3} \%$ & \multicolumn{4}{|c|}{ Size fractions \% } & \multicolumn{4}{|c|}{ Heavy metal in $(\mathrm{mg} / \mathrm{kg})$} \\
\cline { 5 - 12 } & & & clay & silty & sandy & $\mathbf{C d}$ & $\mathbf{C o}$ & $\mathbf{C r}$ & $\mathbf{C u}$ & $\mathbf{N i}$ & $\mathbf{Z n}$ \\
\hline 8,1 & 8.5 & - & 5.8 & 47 & 20 & 33 & $<1$ & 19 & 43 & 22 & 42 & 92 \\
\hline
\end{tabular}

$\mathrm{X}$-ray diffraction is indicated that the soil under forest (Charf) is composed exclusively of smectites. The other minerals are quartz and calcite. Thus for analyzes of infra-red one obtains:

Broadband around $3400 \mathrm{~cm}^{-1}$ is representative of the vibration of the $\mathrm{O}-\mathrm{H}$ bonds (alcohols and acids).

The band at about $1624 \mathrm{~cm}^{-1}$ corresponds to the $\mathrm{C}=\mathrm{C}$ bonds of the aromatic and olefinic compounds.

Two bands between 3000 and $2800 \mathrm{~cm}^{-1}$ are attributed to the valence vibrations of the alkyl groups $\left(-\mathrm{CH}_{3}\right.$, $\left.-\mathrm{CH}_{2},-\mathrm{CH}\right)$.

The $1725 \mathrm{~cm}^{-1}$ band corresponds to the $\mathrm{C}=\mathrm{O}$ vibrations of carbonyls (aldehyde and ketones) and carboxyls (esters and acids).

The band located at about $1461 \mathrm{~cm}^{-1}$ is due to the mode of specific deformation of the $-\mathrm{CH}_{2}$ groups; and the bands which lie between 650 and $900 \mathrm{~cm}^{-1}$ correspond to the deformation vibrations, out of the plane, of the $\mathrm{C}-\mathrm{H}$ bonds of an aromatic ring or an alkene.

\subsection{Soil analysis}

Soil $\mathrm{pH}$ was measured in water, and also in $0.1 \mathrm{M} \mathrm{KCl}$ (soil/solution ratio 1/2.5), using a glass electrode The organic matter $(\mathrm{OM})$ content was determined by the loss on ignition of the dry mass at $550^{\circ} \mathrm{C}$, and the total nitrogen $(\mathrm{Nt})$ - by the Kjeldahl method. The organic carbon content $(\mathrm{Ct})$ has determined using TOC/TNb2100S (Tangier, Morocco) Analytikjena analyzer.

The contents of heavy metals ( $\mathrm{Zn}, \mathrm{Cr}, \mathrm{Pb}, \mathrm{Cd}$, and $\mathrm{As}$ ) in the sediments were determined by Atomic- plasma emission Spectroscopy ICP AES (Ultima 2-JobinYvon) in (CNRST) national center of scientific research. The obtained results have been expressed in $\mathrm{mg} / \mathrm{kg}$. In this work, the choice of these metals takes into consideration those most dangerous and most frequently met in the soil. Moreover, these metals have usually been used in the industrial. 


\subsection{UV-Vis spectroscopy of soil samples}

One gram of each soil sample has weighted into a $250 \mathrm{ml}$ polyethylene flask and extracted with $50 \mathrm{ml}$ of $0.5 \mathrm{MNaOH}$ by shaking for $2 \mathrm{~h}$. After, the flask was left overnight. The next day the suspension was centrifuged at $3000 \mathrm{rpm}$ for $25 \mathrm{~min}$, and the absorbance (A) of the supernatant was measured at $\lambda=280 \mathrm{~nm}$ (A280), $472 \mathrm{~nm}$ (A472) and $664 \mathrm{~nm}$ $(\mathrm{A} 664)^{7}$. The following absorbance ratios indicating the degree of humification were calculated: $\mathrm{Q}_{2 / 6}$ $=\mathrm{A}_{280} / \mathrm{A}_{664}$ and $\mathrm{Q}_{4 / 6}=\mathrm{A}_{472 /} \mathrm{A}_{664}$. The $\mathrm{Q}_{2 / 4}$ reflects the proportion between the lignins and other materials at the beginning of humification and the content of materials at the beginning of a transformation. The $\mathrm{Q}_{2 / 6}$ denotes the relation between non-humified and strongly humified material. The $\mathrm{Q}_{4 / 6}$ is often called the humification index and is the most often calculated ratio. Typical values of the $\mathrm{Q}_{4 / 6}$ ratio for humified material are usually $<5^{8,9}$.

\subsection{FT-IR spectroscopy}

Pellets have prepared by mixing $1 \mathrm{mg}$ of each freezedried sample with $100 \mathrm{mg}$ of $\mathrm{KBr}$ so that the mixture became homogeneous. Infrared spectra have recorded on these pellets with JASCO Corp., FT/IR-410 spectrometer over the $4000-400 \mathrm{~cm}^{-1}$ range.

\subsection{X-ray diffraction}

For X-ray diffraction analysis, samples ground into powder were suspended in deionized, distilled water then smeared on glass slides, air-dried, and analyzed with Diffractometer system=XPERT-PRO (Operator: C.N.R.S.T, morocco) using $\mathrm{Cu}$ as a node Material and generator settings of $40 \mathrm{~mA}, 45 \mathrm{kV}$.

\section{Results}

\subsection{Physicochemical analyze}

Table 2 shows the main physical and chemical characteristics; measurement of electrical conductivity (EC) of the soil is a property that has become one of the methods of measuring soil salinity ${ }^{10}$. For our samples, it has a high conductivity indicating that it is salty; EC values vary between $0.1282 \mathrm{~ms} / \mathrm{cm}$ and $5.91 \mathrm{~ms} / \mathrm{cm}$. These values are relatively high to EC cultivated soil11 and similar to household waste compost values ${ }^{9-11}$.

Table 2. Some physico-chemical parameters of the landfill Tangier soil samples.

\begin{tabular}{|c|c|c|c|c|c|c|c|c|c|c|c|}
\hline \multirow[t]{2}{*}{ Samples } & \multirow{2}{*}{$\begin{array}{c}\text { Dry } \\
\text { Matter } \\
\%\end{array}$} & \multirow[t]{2}{*}{$\begin{array}{c}\mathrm{pH} \\
\text { eau }\end{array}$} & \multirow[t]{2}{*}{$\begin{array}{c}\mathrm{OM} \\
\%\end{array}$} & \multirow[t]{2}{*}{$\begin{array}{c}\mathrm{EC} \\
\mathrm{ms} / \mathrm{cm}\end{array}$} & \multicolumn{2}{|c|}{$\mathrm{CaCO}_{3} \%$} & \multirow[t]{2}{*}{ СOT $\%$} & \multirow[t]{2}{*}{ NOT\% } & \multicolumn{3}{|c|}{$\begin{array}{c}\text { Size fractions } \\
\%\end{array}$} \\
\hline & & & & & total & active & & & clay & silty & sandy \\
\hline charf & - & 8,1 & 8.5 & - & 5.8 & - & - & - & 47 & 20 & 33 \\
\hline$P_{1}$ & 96,86 & 7,40 & 3 & 5,91 & 29,50 & 14,20 & 1,76 & 0,19 & 20 & 60 & 20 \\
\hline $\mathrm{P}_{2}$ & 96,40 & 7,77 & 0,17 & 4,81 & 28,40 & 11,75 & 0,10 & 0,01 & 35 & 45 & 20 \\
\hline $\mathrm{P}_{3}$ & 90,80 & 7,51 & 7 & 3,94 & 25,20 & 9,12 & 2,83 & 0,19 & 18 & 47 & 35 \\
\hline $\mathrm{P}_{4}$ & 96,70 & 7,65 & 3,57 & 3,77 & 26,40 & 10,35 & 4,96 & 0,38 & 22 & 38 & 40 \\
\hline $\mathrm{P}_{5}$ & 88 & 7,60 & 12,41 & 0,13 & 15,90 & 3,25 & 7,50 & 0,27 & 35 & 40 & 25 \\
\hline $\mathrm{P}_{6}$ & 95,40 & 8 & 24 & 3,65 & 17,30 & 5,30 & 14,94 & 0,73 & 18 & 52 & 30 \\
\hline $\mathrm{P}_{7}$ & 99 & 9,07 & 5,40 & 3,33 & 24 & 8,50 & 4,02 & 0,30 & 10 & 50 & 40 \\
\hline $\mathrm{P}_{8}$ & 63,75 & 7,50 & 12,30 & 3,97 & 25,50 & 10,75 & 10,06 & 0,50 & 29 & 52 & 19 \\
\hline
\end{tabular}

The $\mathrm{pH}$ is around neutral except $\mathrm{P}_{6}$ and $\mathrm{P}_{7}$ which is basic, so the medium is neutral-basic. Theoretically, at atmospheric pressure, the $\mathrm{pH}$ of the soil solutions increases with the presence of excess carbonate ${ }^{12}$ due to the nature of the lands (Region rich in limestones) 13. The presence of limestone in the soil causes an increase of the total organic matter content. Most of the values are highly calcareous varied between 15.90 and $29.50 \%$ (According to the International Norm: NF ISO 10693).

For organic matter, the percentage varies from one site to another (from $0.172 \%$ to $24 \%$ ). The organic matter in landfills soils comes from several types of waste fermentable (degraded compounds, cardboard paper ...) and other easily degradable compounds (such as plastics which are essential sources of organic matter) ${ }^{14}$. Indeed, the organic material content is the parameter that has an excellent correlation with the retention power of the organic and metal pollutants by the soil ${ }^{15}$.
The $\mathrm{C} / \mathrm{N}$ ratio does not exceed ${ }^{15}$ in most samples except $\mathrm{P}_{5}, \mathrm{P}_{6}$ and $\mathrm{P}_{8}$, the maximum value (27.77) is observed in the P5and similar to household waste compost values 16,17 . Landfill soil samples are deficient in nitrogen (varies between 0.01 and $0.73 \%$ ). All of the physical and chemical properties of the soil have closely related to structure and texture. Soil particles are classified according to their diameter: sands (from $2 \mathrm{~mm}$ to $50 \mu \mathrm{m}$ ), silts $(50 \mu \mathrm{m}$ to $2 \mu \mathrm{m})$ and clays $(<2 \mu \mathrm{m})$. The distribution of these different particles makes it possible to determine the texture of the soils regardless of the nature and composition of these minerals.

Particle size fractionations have used regularly to measure the structural stability of soil for studying the organic matter associated with stable aggregates. The granulometry study shows that the samples of soils rather coarse, with a predominantly silty texture) (Table 2). This study is realized by two modes (vertical vibration sieving and laser granulometry. 
According to their mineral quality, the silts do not stabilize the soil structure, unlike silts. This distribution indicates, according to the triangle of textures ${ }^{18}$, that the soil of the landfill of Tangier is unstable.

\subsection{Heavy metals}

The results of heavy metals analyses of the superficial landfill soil samples shown in Table 3. Heavy metals are among the principal polluting agents of the soil environment. The more part of them is generally associated with the suspended matter or to the sediments; in particular, those of the surface layer because it is where the phenomena of adsorption are most active. They could have two possible origins: natural origin by partial degradation of the rocks or an industrial origin related to the human activity ${ }^{19,20}$. The concentrations of heavy metals in the landfill of Tangier exceeding those authorized in landfill soil in other landfills ${ }^{21}$, these high values of heavy metals in soils can be attributed to nature and waste composition. Metal pollution of buried waste is a long-term problem; metals have distributed in the soil in various forms.

The five heavy metals cited in the study: $\mathrm{Pb}, \mathrm{Cd}$, As, $\mathrm{Cr}$, and $\mathrm{Zn}$. The results show in the different samples vary from 1,286 at $4,414 \mathrm{mg} / \mathrm{kg}$ for cadmium; and from 4.47 at $7.30 \mathrm{mg} / \mathrm{kg}$ Arsenic; and from 85.72 at
$340.84 \mathrm{mg} / \mathrm{kg}$ for Chrome; and from 44.44 to298.36 $\mathrm{mg} / \mathrm{kg}$ for lead; and from 488.9 to $16117.7 \mathrm{mg} / \mathrm{kg}$ for zinc.

$\mathrm{Pb}$ is toxic and is one of the least mobile metallic elements in the soil. It found commonly in household waste in developing countries because of its use as a component of cells ${ }^{22}$.

The average concentration area beyond AFNOR (norm NF U 44-041) ${ }^{19}$ except $\mathrm{P}_{1}$ (Table 3), but that is below that of other landfills in the world. The cadmium can generate by batteries but also plastics, glass, and metals ${ }^{22}$. The total middle of the $\mathrm{Cd}$ is higher than the AFNOR norm ${ }^{23}$. Among the studied of heavy metals, the zinc concentrations have very high levels in landfill soils than that in natural soils ( 5 to 127 times higher in landfills than in natural soils ${ }^{24}$. The concentration of zinc in our study far exceeds the thresholds recommended by the AFNOR norm $(300 \mathrm{mg} / \mathrm{kg}$ ). Thus, the average concentration of $\mathrm{Cr}$ detected in the $0-20 \mathrm{~cm}$ depth is higher than that found by $\mathrm{CCME}^{25}$; it is minimal compared to the AFNOR norm $^{23}$. The high concentration of $\mathrm{Cr}$ can be explained by its anthropogenic in solid waste ${ }^{26,27}$.

The concentration of As is low compared to that found by $\mathrm{CCME}^{25}$ and to other landfills (Table 3). The presence of heavy metals in the discharge is not uniform. This is due not only to the heterogeneity of the waste but also to the non-uniform degradation of this waste.

Table 3. Heavy metal content expressed in $(\mathrm{mg} / \mathrm{kg})$ of the Tangier landfill and other landfills; comparison with values given by AFNOR and CCME.

\begin{tabular}{|l|l|c|c|c|c|c|}
\hline Landfill & & As & Cd & Cr & Pb & Zn \\
\hline Tangier Morocoo & $\mathrm{P}_{1}$ & 3,175 & 7,302 & 85,716 & 44,445 & 488,899 \\
\cline { 2 - 7 } & $\mathrm{P}_{3}$ & 1,855 & 5,964 & 119,278 & 106,02 & 975,431 \\
& $\mathrm{P}_{4}$ & 1,676 & 4,469 & 119,827 & 135,189 & 657,79 \\
\cline { 2 - 7 } & $\mathrm{P}_{5}$ & 1,286 & 4,716 & 340,836 & 151,983 & 16117,702 \\
\cline { 2 - 7 } & $\mathrm{P}_{6}$ & 2,548 & 5,096 & 129,94 & 185,993 & 13834,81 \\
\cline { 2 - 7 } & $\mathrm{P}_{7}$ & 4,414 & 5,885 & 107,106 & 298,366 & 3078,697 \\
\cline { 2 - 7 } & $\mathrm{P}_{8}$ & 1,536 & 6,145 & 92,17 & 156,177 & 1461,918 \\
\hline Ahfir-Saidia(Morocoo) [27] & 33,96 & - & 75,74 & 656,46 & 62,87 \\
\hline Akouédo Abidjan[1] & - & $1-11,5$ & $27,7-125$ & $10,3-1500$ & $18,6-1163,7$ \\
\hline Al Ain (Emirats Arabes & - & 0,043 & 19,1 & 13,7 & 117 \\
\hline Unis)[1] & - & & & - & $13,2-1008$ \\
\hline Mal(NewJersey) [1] & - & 2 & $6,55-4,6$ & 1260 & 300 \\
\hline France [23] & 12 & 1,4 & 64 & 70 & 200 \\
\hline Canada [25] & 51,7 & - & 127,9 & 206,4 & 122,3 \\
\hline India [27] & & & & & 100 \\
\hline
\end{tabular}

\subsection{FTIR spectra}

The FTIR spectra of all seven samples were very similar in terms of the position of principal absorption bands and shoulders (Figure 2). Fine bands located at 3697,3650 and $3619 \mathrm{~cm}^{-1}$ corresponding to stretching vibration of the $\mathrm{OH}$ group of the $\mathrm{Si}-\mathrm{O}-\mathrm{H}$ respectively kaolinite and silicates ${ }^{28,29}$.

All of the spectra have characterized by strong bands at around $3403 \mathrm{~cm}^{-1}$ for $\mathrm{O}-\mathrm{H}$ groups of alcohols, phenols, and organic acids. $1636 \mathrm{~cm}^{-1}$ mainly for $\mathrm{C}=\mathrm{C}$ stretching vibration of aromatic rings. The bands at
$1433 \mathrm{~cm}^{-1}$ and $874 \mathrm{~cm}^{-1}$ for $\mathrm{C}=\mathrm{O}$ asymmetric stretching, O-H deformation and $\mathrm{C}-\mathrm{O}-\mathrm{H}$ deformation of carboxyl groups. The bands at 1102.1, 1162.8 and $921 \mathrm{~cm}^{-1}$ can be attributed to $\mathrm{C}-\mathrm{O}$ stretching of carbohydrates, polysaccharides, acids, esters and ethers Amide III, acid or aliphatic alcohols, deformation of $\mathrm{C}-\mathrm{O}$ and $\mathrm{O}-\mathrm{H}$ the carboxylic groups, compounds organo-sulfurs -C-O-C particularly, $\mathrm{Si}-\mathrm{O}-\mathrm{C}$ grouping ${ }^{26}$. The bands at $1433 \mathrm{~cm}^{-1}$ and $874 \mathrm{~cm}^{-1}$ are similar to the results of pure calcite spectra (calcium carbonate $\mathrm{CaCO} 3)^{30}$. The Two sharp bands at about $2922 \mathrm{~cm}^{-1}$ and $2854 \mathrm{~cm}^{-1}$ due to 
aliphatic $\mathrm{C}-\mathrm{H}$ group stretching, this band are more noticeable on $\mathrm{P}_{3}$.

The band at $695 \mathrm{~cm}-1$ is associated with the deformation of the Si-O bonds of the Kaolinite and the band (a shoulder in some cases) at $1799 \mathrm{~cm}-1$ is attributed to the $\mathrm{C}=\mathrm{O}$ stretching vibration of $\mathrm{COOH}$, ketones, aldehydes and esters, this band very intense in $\mathrm{P}_{7}$ spectra.

Finally, in all spectra, a peak was detected at $1080-1030 \mathrm{~cm}^{-1}$ and ascribed to the $\mathrm{C}-\mathrm{O}$ stretching of polysaccharides and/or to $\mathrm{Si}-\mathrm{O}$ vibrations of silicate impurities (is more intense for the samples $\mathrm{P}_{5}$ et $\mathrm{P}_{8}$ ). Thus, the peaks between 520 and $470 \mathrm{~cm}^{-1}$ are due to para-di-substituted aromatic groups ${ }^{31}$.

Although the FTIR spectra seemed very similar, differences across the spectra were apparent in terms of the relative intensity of some bands, depending on the landfill depths position.



Figure 2. The FT-IR spectra of the soil of the eight different points of the Tangier landfill

\subsection{X-ray diffraction}

The X-ray diffraction is an analytical technique based on the X-ray diffraction on the material (This technique defines micro mineral phases and polycrystalline materials. X-Ray Diffraction(XRD) has performed to determine the mineralogical 
composition of the six soil samples $\left(\mathrm{P}_{1}, \mathrm{P}_{3}, \mathrm{P}_{4}, \mathrm{P}_{5}, \mathrm{P}_{7}\right.$ and $\mathrm{P}_{8}$ ) (Figure 3).

Figure 3 shows the proportion of quartz and calcite (the peaks located at 4,26 $\AA$ and $3,34 \AA$ ) contained in almost all the diffraction patterns of soil landfill samples.
Soil samples are composed in addition to quartz and calcite, kaolinite $\left[\mathrm{Al}_{2} \mathrm{Si}_{2} \mathrm{O}_{5}(\mathrm{OH})_{4}\right]$, Halite and muscovite, vanadian $\mathrm{K}(\mathrm{Al}, \mathrm{V})_{2}(\mathrm{Si}, \mathrm{Al})_{4} \mathrm{O}_{10}(\mathrm{OH})_{2}$ ] for $\mathrm{P}_{1}$, of kaolinite $\left[\mathrm{Al}_{2} \mathrm{Si}_{2} \mathrm{O}_{5}(\mathrm{OH})_{4}\right]$ for $\mathrm{P}_{8}$, hematite $\left(\mathrm{Fe}_{2} \mathrm{O}_{3}\right)$ for $\mathrm{P}_{7}$. These results are confirmed by SEM analyzes.
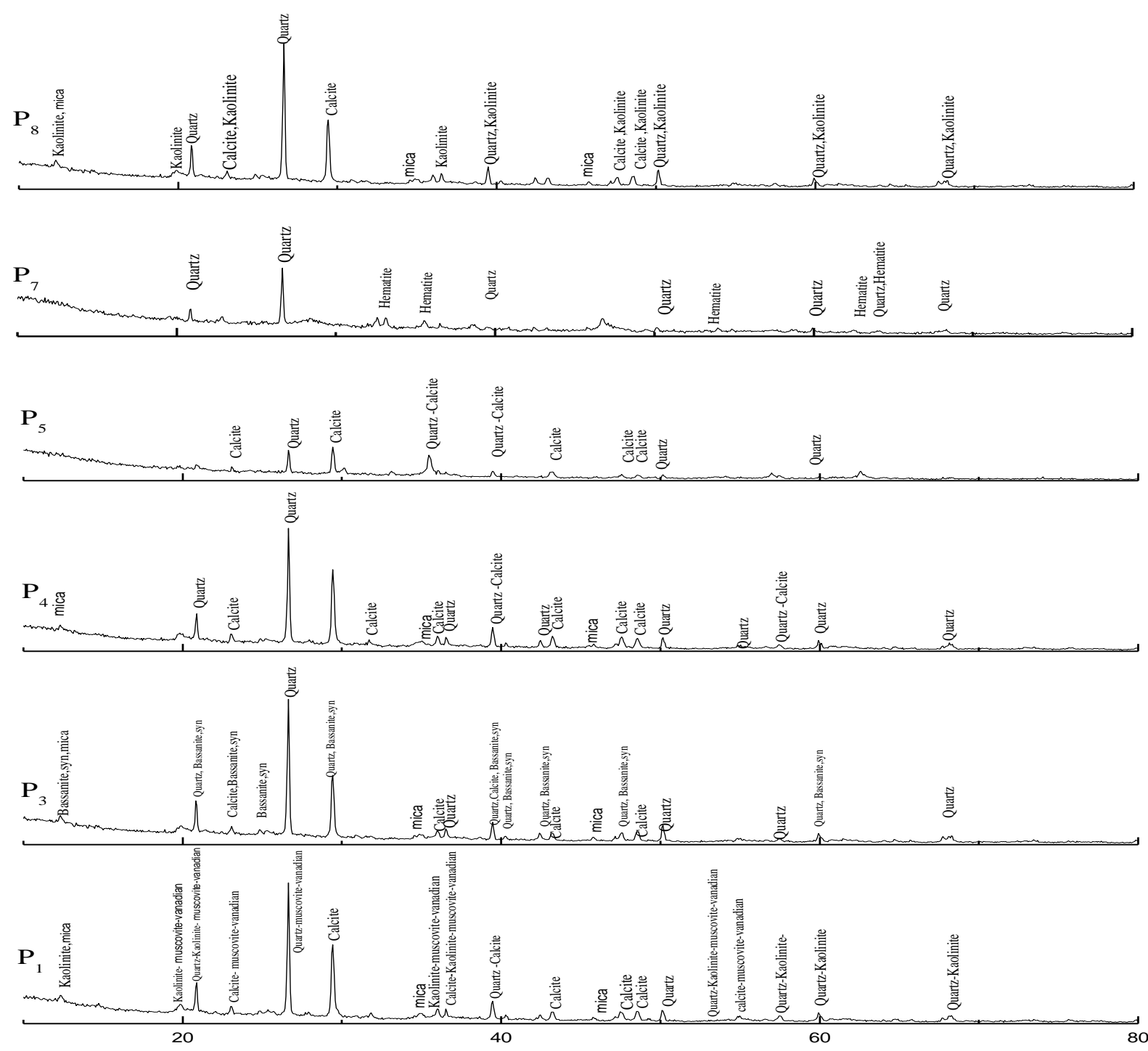

Figure 3. X-ray diffraction patterns of eight samples landfill soil samples at different positions

\subsection{Electronic scanning microscope analyze} (SEM)

Figure 4 shows the photograph taken at SEM with an EDS spectrum of Tangier landfill $\left(\mathrm{P}_{3}\right)$. SEM results show that they mainly consist of quartz and numerous alloys based on $\mathrm{Si}, \mathrm{Ca}, \mathrm{Fe}, \mathrm{Al}, \mathrm{Zn}, \mathrm{Mg}$...
The two images in Figure 5 have demonstrated the existence of intra-granular porosity (rough surfaces and cracks) which are all factors leading to overestimation of the actual surface area of the landfill soil. 

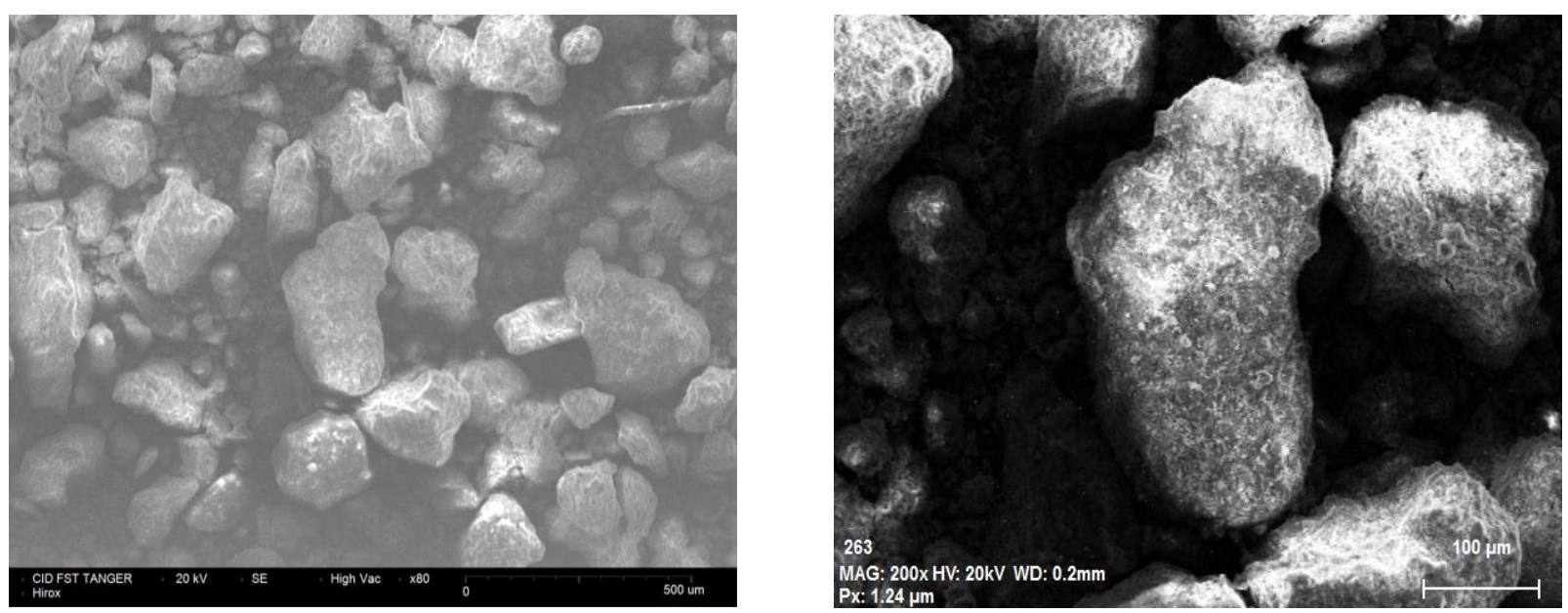

\begin{tabular}{|l|l|}
\hline Eléments & {$[\%]$} \\
\hline Oxygène & 13.80 \\
silicium & 15.29 \\
carbone & 8.14 \\
aluminium & 4.53 \\
calcium & 2.55 \\
fer & 1.36 \\
magnésium & 0.77 \\
soufre & 0.10 \\
plomb & 0.05 \\
cuivre & 0.09 \\
zinc & 0.15 \\
\hline
\end{tabular}



Figure 4. Shows the photograph taken at SEM with an EDS spectrum of Tangier landfill $\left(\mathrm{P}_{3}\right)$



Figure 5. Picture SEM of $\mathrm{P}_{3}$ grain Tangier landfill, fraction $<80 \mu \mathrm{m}$

\subsection{UV - visible spectroscopy}

Many authors have used UV-Visible spectroscopy to characterize the degree of humification and stability of organic matter. According to the work of Swift, Kononova, Chen et al. and Stevenson ${ }^{32-35}$, the ratio
$\mathrm{Q}_{4} / \mathrm{Q}_{6}$ has used as an index of humification. In the same principle, Zbytniewski \& Buszewski ${ }^{9}$ identified three main areas within the spectra of alkaline extracts compost or soil. 
Table 4. $\mathrm{Q}_{4 / 6}\left(\mathrm{Q}_{472 / 665}\right)$ and $\mathrm{Q}_{2 / 6}\left(\mathrm{Q}_{280 / 665)}\right.$ ratios of landfill soil samples at different position.

\begin{tabular}{|c|c|c|}
\hline Samples & $\mathrm{Q}_{472 / 664}$ & $\mathrm{Q}_{280 / 664}$ \\
\hline $\mathrm{P}_{1}$ & $\mathbf{9 , 8 2}$ & $\mathbf{4 8 , 7 8}$ \\
\hline $\mathrm{P}_{2}$ & $\mathbf{1 1 , 7 2}$ & $\mathbf{2 0 , 3 5}$ \\
\hline $\mathrm{P}_{3}$ & $\mathbf{9 , 4 0}$ & $\mathbf{2 1 , 5 0}$ \\
\hline $\mathrm{P}_{4}$ & $\mathbf{6 , 2 2}$ & $\mathbf{1 4 , 4 0}$ \\
\hline $\mathrm{P}_{5}$ & $\mathbf{3 , 9 1}$ & $\mathbf{3 8 , 7 7}$ \\
\hline $\mathrm{P}_{6}$ & $\mathbf{4 , 4 9}$ & $\mathbf{8 , 3 2}$ \\
\hline $\mathrm{P}_{7}$ & $\mathbf{1 1 , 7 6}$ & $\mathbf{3 6 , 9 2}$ \\
\hline $\mathrm{P}_{8}$ & $\mathbf{7 , 5 3}$ & $\mathbf{6 9 , 8 4}$ \\
\hline
\end{tabular}

The region between 460 and $480 \mathrm{~nm}$ correspond to the organic matter at the beginning of humification and the absorbance 600-670 nm corresponds to highly humified matter.

These ratios were calculated for 8 samples of the soil, and the results are expressed in Table 4.

Decreases reports $\mathrm{Q}_{2} / \mathrm{Q}_{6}$ and $\mathrm{Q}_{4} / \mathrm{Q}_{6}$ indicate increased strongly humified organic matter in the soil and reflect a high degree of aromatic condensation and indicate a higher level of organic material humification ${ }^{35,36}$. These results indicate that the landfill soil samples are in early humification (characterized by a large amount of fulvic acid and low molecular weight $\left(\mathrm{Q}_{4} / \mathrm{Q}_{6}>5\right)^{37}$.

\section{Conclusion}

This work brings to understanding the different components of soil in a landfill.

The organic material content is the parameter that has a perfect correlation with the retention power of the organic and metal pollutants by the soil.

Our soil is very rich with limestone (moderately and strongly calcareous), and the $\mathrm{C} / \mathrm{N}$ ratio does not exceed 15 in most samples.

Thus, the medium concentrations of heavy metals observed are higher than the standard reference values and other landfills of polluted soils, especially Zinc, whose origin is probably anthropogenic (industrial waste).

For Spectroscopic (infrared and UV-visible) analysis, the results indicate that these soils are high molecular weight organic compounds (humic substances).

Finally, analyzes of SEM showed the presence of intra-granular porosities in grains. Moreover, the landfill Soil samples are composed of quartz and calcite the many mineral composites.

\section{References}

1- I.K. Kouame, D.L. Gone, I. Savane, E. A. Kouassi, K. Koffi, M. Goula, B.T.A. Diallo, Mobilité relative des métaux lourds issus de la décharge d'Akouédo et risque de contamination de la nappe du Continental Terminal (Abidjan Côte d'Ivoire), Afrique Science. 2006, 02(1), 39-56.
2- K. Klein, A. Kivi, N. Dulova, I. Zekker, E. Mo“lder,T. Tenno, M. Trapido, T. Tenno, A pilot study of three-stage biological-chemical treatment of landfill leachate applying continuous ferric sludge reuse in Fenton-like process, Clean Techn Environ Policy., 2017, 19. 541-551.

3- T.V. Ramachandra, H.A. Bharath, G. Kulkarni, S.S. Han, Municipal solid waste: Generation, composition and GHG emissions in Bangalore, India. Renewable and Sustainable Energy Reviews, 2018, 82, 1122-1136.

4- A. Tahiri, A. Richel., J. Destain, P. Druart, P. Thonart, M. Ongena, Comprehensive comparison of the chemical and structural characterization of landfill leachate and leonardite humic fractions, Analytical and bioanalytical chemistr., 2016, 408, 1917-1928.

5- V. Vilar, E. Rocha, F. Mota, A. Fonseca, I. Saraiva, R. Boaventura, Treatment of sanitary landfill leachate using combined solar photoFenton and biological immobilized biomass reactor at a pilot scale. Water Res., 2011, 45, 2647-58.

6- S. Renou, J.G. Givaudan, S. Poulaina, F. Dirassouyan, P. Moulin, Landfill leachate treatment: review and opportunity. J. Hazard Mater., 2008, 150, 468-93.

7- B. Sapek, A. Sapek, Determination of optical properties in weakly humified samples. In: H. Dziadowiec, S.S Gonet. (Eds.), The Study of Soil Organic Matter - the Methodical Guide. Warszawa, Poland, 1999.

8- E. Gieguzynska, A. Kocmit and D. Golebiowska, Studies on humic acids in eroded soils of. Western Pomerania. In: Humic Substances in Ecosystems, 1998, 3, 35-41.

9- Zbytniewski. R, Buszewski B. Characterization of natural organic matter (NOM) derived from sewage sludge compost. Part 2: multivariate techniques in the study of compost maturation. Bioresour. Technol., 2005, 96, 479-484.

10- M. D. Zaafour, Impact des décharges sauvages sur les Zones Humides de la région d'El-Tarf. Annaba. 2012, pp. 166.

11- I. Jemai, S.B. Guirat, N. B. Aissa, N. Jedidi, T. Gallali, Effet de l'amendement par fumier de ferme et par compost d'ordures ménagères sur la restauration d'un sol argileux de plaine sous 
climat semi-aride tunisienEtude et gestion des sols, 2011, 271-285.

12- M. Giroux, P. Audesse, Comparaison de deux méthodes de détermination des teneurs en carbone organique, en azote total et du rapport $\mathrm{C} / \mathrm{N}$ de divers amendements organiques et engrais de ferme. Agrosol., 2004, 15, 107-110.

13- M. Elafia, B. Damnati, H. Bounouira, K. Embarch, H. Amsil, M. Bounakhla, M.Tahri, and I. Aarab, Water Quality of El Hachef River (Region of Tangier-Tetouan-AL Houceima, North West Morocco): Vol 3: Advanced Intelligent Systems Applied to Environment, Springer Nature Switzerland AG 2019 M. Ezziyyani (Ed.): AI2SD 2018, AISC 913, 2019, 61-72.

14- M. P. Bernal, S. G. Sommer, D. Chadwick, C. Qing, L. Guoxue, and F. C. Michel, Current approaches and future trends in compost quality criteria for agronomic, environmental, and human health benefits. Adv. Agron. 2017, 144, 143-233.

15- F. Letacon. La présence de calcaire dans le sol. Influence sur le comportement de l'Epicéa commun (Picea exce/sa Link.) et du Pin noir d'Autriche (Pinus Nigra nigricans Host.), Ann. Sei. Forest. 1978, 35, 165-174.

16- S. Sadaka, A. El-Taweel, Effects of aeration and $\mathrm{C} / \mathrm{N}$ ratio on household waste composting in Egypt, Compost Science \& Utilization, 2003, 11 (1), 36-40.

17- T. Eggen, O. Vethe, Stability indices for different composts. Compost Science and Utilization, 2001, 9(2), 19-36.

18- G. Monnier, P. Stengel, Rôle des propriétés d'origine texturale dans les processus d'organisation structurales des sols, Science du Sol, Bulletin de l'A.F.E.S, 1976, 02,131-138.

19- A.J.M Baker, R.R. Brooks, Terrestrial higher plants which hyperaccumulate metallic elements - a review of their distribution, ecology and phytochemistry, Biorecovery, 1989, 01, 81-126.

20- D. Chabert, Pollution d'un milieu lagunaire parles métaux lourds. Vie marine, 1980, 02,145.

21- I. Chaer.A, El Cadi, A. L. Fakih, M. Khaddor, J. Brigui, Détermination du degré de contamination du site de la décharge, non contrôlée, de la ville de Tanger par quelques métaux lourds . J. Mater. Environ. Sci., 2016, 7 (2), 541-546.

22- M.M. Mokhtaria, B.B. Eddine, D. Larbi, H. Azzedine, L Rabah, Caractérisation de la décharge publique de la ville de Tiaret et son impact sur la qualité des eaux souterraines, Courrier du Savoir, 2007, 08, 93-99.

23- AFNOR (Association française de normalisation), Qualité des sols. Recueil de normes françaises. 3e. 1996, 534.

24- C. Aulin, I. Neretnieks, A Material balance for an Industrial Landfill, In Proceeding Sardinia, 5th International Waste Management and Landfill Symposium, Cagliari Italy, 1997, 173-180.
25- CCME, Interim Canadian environmental quality criteria for contaminated sites, Winnipeg. 1999.

26- C.H. Jung, T. Matsuto, N. Tanaka.J, Flow analysisof metals in a municipal solid waste management system. Waste Manage, 2006, 26, 1337-1348.

27- F. Nhari, M. Sbaa, J. L. Vasel, M. Fekhaoui, M. El Morhit, Contamination des sols d'une décharge non contrôlée par les métaux lourds : cas de la décharge Ahfir- Saidia (Maroc oriental).J. Mater. Environ. Sci., 2014, 05, 1477-1484.

28- G. Haberhauer, M.H, Gerzabek. FTIRspectroscopy of soils - characterization of soil dynamic processes, Trends Appl. Spectrosc., 2001, 03, 103-109.

29- M. Tatzber, M. Stemmer, H. Spiegel, C. Katzlberger, G. Haberhauer, M.H. Gerzabek, An alternative method to measure carbonate in soils by FT-IR spectroscopy.Environ. Chem. Lett., 2007, 05, 9-12.

30- G. Haberhauer, M.H. Gerzabek, FTIRspectroscopy of soils-characterization of soil dynamic processes. Trends Appl. Spectrosc., 2001, 03, 103-109.

31- M. Koriko, S. Tcheguni, K. E. Koledzi, D. D. Bafai, E. Zonvidey, G. Tchangbdji, A. K Kili et M. Hafdi, Extractions et caractérisations physicochimiques des substances humiques naturelles des sols et du compost, Int. J. Biol. Chem. Sci., 2013, 7(3) , 1405-1415.

32- R. S. Swift, Organic matter characterization.In: Methods of Soil Analysis, Part 3: Chemical Methods. D. L. Sparks, et al. (eds.), SSSA Book Series No. 5, SSSA and ASA, Madison, WI. 1996, 1011-1069.

33- M. M. Kononova, Soil organic matter, Pergamon, New York, 1966, 544.

34- Y. Chen, N. Senesi, M. Schnitzer, Information provided on humic substances by E4/E6 ratios. Soil Science Society of America Journal, 1977, 41, 352-358.

35- F.J. Stevenson, Humus chemistry, Genesis, Composition, Reaction. Johan Wiley and Sons, Inc, Second Edition, New York, 1994, 350.

36-M. Domeizel, A. Khalil \& P. Prudent, UV spectroscopy: a tool for monitoring humification and for proposing an index of the maturity of compost. Bioresource Technology, Bioresource Technology, 2004, 94, 177-184.

37-S. Amir, M. Hafidi, L. Lemee, J.R. Bailly, G. Merlina, M. Kaemmerer, J.C. Revel, A. Ambles, Structural characterization of fulvic acids, extracted from sewage sludge during composting, by thermochemolysis-gas chromatography-mass spectrometry, Journal of Analytical and Applied Pyrolysis, 2006, 7, 149-158. 